Article

\title{
Cycle Tourism as a Driver for the Sustainable Development of Little-Known or Remote Territories: The Experience of the Apennine Regions of Northern Italy
}

\author{
Patrizia Gazzola ${ }^{1, *(1)}$, Enrica Pavione ${ }^{1}$, Daniele Grechi ${ }^{1}$ (i) and Paola Ossola ${ }^{2}$ \\ 1 Department of Economics, University of Insubria, 21100 Varese, Italy; enrica.pavione@uninsubria.it (E.P.); \\ grechi.daniele@uninsubria.it (D.G.) \\ 2 César Ritz Colleges, 3902 Brig, Switzerland; paola.ossola@cesarritzcolleges.edu \\ * Correspondence: patrizia.gazzola@uninsubria.it; Tel.: +39-0332-395529
}

Received: 28 February 2018; Accepted: 30 May 2018; Published: 4 June 2018

\begin{abstract}
One form of cycle tourism can be represented features tourism that focuses on the relation between biking and the discovery of a territory. Geared toward forms of holiday that allow for the low consumption of natural resources and a connection with the landscape, cycle tourism represents a concrete expression of sustainable tourism. As an emerging phenomenon in Italy, cycle tourism requires further understanding in order to identify methods of development and applicable business models. The aim of this paper is to explore the characteristics of cycle tourism's development in northern Italy in order to identify the links that exist between sustainability and the group of cycle tourists who prefer to spend their holidays discovering little-known or remote territories. For this study, we selected three different destinations in sensitive mountain areas that converge on the common goal to use cycling to rejuvenate the tourism sector. It has been found that the development of cycle tourism in areas not characterized by mass tourism, such as those considered here, is economically, socially, and environmentally beneficial. The business models through which cycle tourism usually develops include a bottom up approach or a top down approach, involving the cooperation of several local destination stakeholders.
\end{abstract}

Keywords: cycle tourism; sustainable development; little-known or remote territories; sustainable mountain tourism

\section{Introduction}

In recent years, the tourism sector has been located between the demand and supply sides with changes that focus attention on binomial territory-tourism as a relevant force for developing tourism offers and increasing competitiveness. A significant number of studies underline the important variations of consumption patterns [1-3]. Until the 1970s, the tourist was essentially a mass consumer; however, the subsequent social and environmental consequences of this practice, which have emerged in recent decades, have produced a growing demand for experiential and emotional holidays, with a unique character that differs from the classic, standardized holiday [4]. The tourist is now figured as a traveler who pursues experiences in the direction of leisure, landscape, and learning [5].

In this context, the tourist has a marked sensitivity to different and innovative features of leisure time and is usually focused on the discovery of the fundamental characteristics of an area sought through a new set of relations based on local contacts and people. Tourists are looking for a complex and profound experience to better appreciate the elements of local identities and the unique landscapes of a precise territory [6,7]. They travel for a unique tourism experience that differs significantly from 
mass tourism experiences [8], looking for traditional characteristics of territories based on tangible and intangible elements [9,10], and stakeholders relationships [11] in a multi-purpose perspective [12-14].

Little-known or remote destinations play an important role in this situation, as they are a pull factor $[15,16]$ for this type of tourist, who can boost their quality of life while combining relaxation and learning [17]. These tourists base their holiday decisions on the availability of tourism offers that create value based on the relational component of the tourism experience, a characteristic embedded in the community and in sustainability practices $[18,19]$, and they look for tourism opportunities that integrate the sociocultural dimension with the environmental one, promoting a genuine exchange between tourists and locals [20-25].

In a particular region, it is possible to find specific expertise and resources that characterize that area as "slow" [25-27]. This term refers to the region's development approach, the quality of services, and the lifestyle. Most little-known or remote territories include features such as a low population density, mountainous location areas $[25,28]$, and a rural setting. Moreover, these territories have an important heritage of tangible and intangible resources (art, food and wine, landscape, etc.) but are not well known. The common feature is a high-quality landscape with a strong synergy between local actors [29-31] and local history and traditions that configure these areas as cultural districts [32-34]. The strong link between the local community, the territory, and the local businesses is the essential element to develop a unique value proposition, where innovative connections between local stakeholders and the cultural roots of the territory create a strong local identity [35]. When discussing little-known or remote territories, it is essential to bring the concept of sustainability into the conversation. Wide reaching, this concept embraces the economic, environmental (physical integrity, environmental purity, biodiversity, and resource efficiency), and social (visitors fulfilment, local control, community wellbeing, social equity, cultural richness) dimensions of sustainability [36-42]. In such territories, it is possible to develop attractive tourism offers under the concepts of slow tourism where visitors' fulfilment goes through local governance to develop sustainable tourism [43] with offers able to create a unique experience [44,45]. Indeed, sustainable tourism clearly highlights the interconnection between the different dimensions that matter for tourists and the locals, an interconnection that allows mutual benefits for the development of a tourism offer for both current and future generations [46]. This requires managerial abilities that enable the genuine development of forms of tourism that spread positive effects while minimizing negative impacts [47,48]. According to Goossens [49], the development of sustainable tourism is driven by psychological and emotional reasons that are foundational to the development of little-known or remote destinations. In these territories, the traditional paradigm of local development no longer works [50,51]. Promoting territories by linking the promotion to environmental and social characteristics rather than just simply focusing on their economic viability is essential to attract potential tourists who are no longer looking for mass tourism opportunities but who are looking for circumstantial or deliberate tourism offers [52] in destinations where they can enjoy a personalized offer linked to their lifestyle and interests. To create such a tourism offer, local private and public stakeholders have strategic roles to play [53]. To increase destination competitiveness, attractiveness, and offers [10], enable individual actor's success, and coordinate resources that belong to different organizations embedded in large, complex networks of co-producing actors [54-58] that are engaged in different functions [59], cooperation and collaboration efforts among different stakeholders is required [60,61]. Moreover, successful cooperation and collaboration enable everyone involved to reap greater benefits [56,57]. Successful cooperation and collaboration avoid typical fragmentation, which $[62,63]$ reduces opportunism and free-loading [60] and increases opportunities for stakeholders to see themselves as colleagues and not as competitors [55,60], eventually developing a high level of trust [64]. By establishing a positive, cooperative, and strong relationship among stakeholders, tourists can enjoy the slow offer, getting in touch with the environmental and cultural richness of the destination [65]. Therefore, a destination governance institution that is capable of developing a strategic plan for leveraging local business development and promoting cooperation is needed $[53,66]$. According to Cantone, Risitano, and 
Testa [67], the local government has an important role in aiding coordination: it facilitates interactions between local stakeholders and the territorial resources whose deployment is needed to achieve the territorial strategy [68], since government efforts allow for a higher level of long-term coordination of different individual efforts [63,69]. Unfortunately, although the literature shows the best methods for creating a strong tourism offer, the required coordination efforts in many destinations, especially in the mountain areas, is lacking. This requires that researchers identify ways through which the activities of different stakeholders can be coordinated to support niche and sustainable tourism [70]. The creation of a product club, for instance is one way for tourism developers in little-known or remote territories to differentiate themselves in the global market. According to this method, a group of operators proposes to share economic and promotional-commercial advantages on the market. It is a form of aggregation between companies with the aim of creating a specific tourism product for a specific market. It represents a new form of offer that enters into a strategic competitive niche to differentiate the tourist offer in an innovative way. A product club is an all-Italian experience partially related to the role of "industrial districts". In these regions, the interrelations-the links that are created between actors across a territory-can increase their competitive advantages. For these purposes, the territory must not be only a scenario or a landscape, but it should become the first factor of attraction for the creation of a successful reference model with a network approach [71,72] without forgetting the promotion factors $[29,73]$.

A product club can differentiate local offers in an innovative manner that involves stakeholders' engagement, cooperation, and coordination, increasing the attractiveness of the destination and improving the competitiveness of SMEs located in the territory [74]. Due to their potential success, some destinations have already decided to invest in product clubs by developing and implementing sustainable projects, and they are strongly advertising the opportunity for different organizations to join them to be able to get the benefits of cooperation [75] that might be impossible to achieve individually $[75,76]$.

One of the niche tourism markets where the concepts of sustainability, mountain territories, and product clubs clearly intersect is that of cycle tourism, which is benefitting from an increasing number of partnerships between private and public organizations that generate greater competitiveness and sustainability, a priority on the governance institution's agenda, especially in destinations that are looking for rejuvenation $[77,78]$. Cycle tourism is an important part of sustainable tourism initiatives. This tourism offers enviable opportunities in destinations that are still not subject to mass tourism, where tourists can discover unspoiled territories on a bike $[79,80]$. Well developed in many European countries, in both rural or non-rural environments, cycle tourism is a form of slow tourism that allows tourists to experience a territory where the environmental and social dimensions of life are conserved. The quality of the landscape, the gastronomy, the agriculture, the local culture and traditions, and sustainability are the competitive advantages of cycle tourism, and these are the elements tourists are looking for and for which they are willing to pay a premium price $[81,82]$. There are different types of cycle tourists [83-85], and these types are delineated by both cycling and non-cycling activities. This paper will refer to the cycle tourer, as a category of cycle tourists, who spends vacations cycling from one destination to the next. Cycle tourers are people taking traditional cycling holidays traveling to a different destination by cycling each day [83-86]. The bike is the mode of transportation that allows the tourist to discover the territory in a way that connects him with the environment $[79,86]$ and social dimensions while obtaining physical and mental benefits $[42,87]$. The bicycle, the means of transportation used by the tourist, becomes a form of tourism as well [88]. Through this form of transportation, whose choice is the core motivation of travelling, tourists can also discover territories with plenty of points of interest [89], promoting a virtuous loop based on a new leisure time approach [90] linked to individual lifestyles [26,91]. Cycling routes are considered open-air gyms and are an innovative and slow way to discover a territory and its points of interest [34]. Cycle tourers in Italy are typically relatively young people with a high level of education who are 
looking for appropriate infrastructure for their trip (e.g., public transportation) as well as for sport activities and cultural initiatives [92].

Cycle tourism, as has been argued, is a form of sustainable tourism that, if correctly developed and managed, can bring positive effects to the local economy $[93,94]$. Evidence of this has been found in the literature, since although these tourists might not constitute a large segment, tourers do spend money on direct tourism activities (e.g., overnight stays [95]) and other tourism related activities (e.g., culinary experiences, visiting museums and cultural sites and museum, hiking) [96]. This form of tourism could represent new forms of economic development for local communities and more sustainable tourism $[97,98]$.

Although cycle tourism has several strengths, to be developed, it needs the local stakeholders to identify this as an opportunity and work together to develop an attractive offer based on a solid cooperative marketing strategy that aligns local management with the principles of bicycle tourism and sustainability [99]. Cooperation and coordination of efforts allows for the development of cycle routes rich in cultural and environmental excellence that can be taken in from a slow perspective, far away from mass tourism [70]. This requires local stakeholders to structure an organic and complete system for their tourism offer, and this process is facilitated by the creation of product clubs, which will increase the competitiveness and the attractiveness of the destination, going above and below the administrative and bureaucratic borders and involving all the interested stakeholders [100-102]. If such an organic and complete system of tourism is created, the competitiveness and the profitability of each single organization in the destination will increase, allowing them to benefit from cycle tourism development [80]. Territories involved in cycle tourism are positively impacted by cycle tourism development.

\section{The Role of Cycle Tourism}

Cycle tourism enhances the social, environmental, and economic status of a territory $[99,103,104]$. Moreover, it benefits each of these aspects of the local communities. In terms of economic and social benefits, cycle tourism increases destination occupancy rates (direct, indirect, and induced job opportunities) [105], competitiveness, and attractiveness in those areas that are at the margin of mass tourism, creating great opportunities for slow tourism development and allowing the public to learn about these destinations [85,106]. These features benefit both locals and visitors [107], including the aforementioned cycle tourers [83-86].

Moreover, cycle tourism creates new job profiles (cycle tourism guide and mobility manager) that emerge to meet the technical requirements of cycle tourists and their need for mobility [80]. Additionally, it improves sustainable transport and promotes wellness [108,109], which further improves local residents' quality of life [85,110]. This is achieved by offering several complementary tourism activities (e.g., food and beverage outlets, rental and maintenance shops, and bicycle TOs [111]), a bundle product for a greater tourism experience [99,112], opportunities to cope with seasonality [113], health benefits and reduction of health costs for the entire system [114]. The environment also benefits from cycle tourism development thanks to conservation of old, disused railways and old country tracks for the construction of new cycle routes [104,115], the creation of a network of green roads [109,116], and the reduction of pollution $[91,117]$. The literature review allows us to conclude that cycle tourism should be considered as a driver of local development that, through cooperation, is able to bring economic, social, and environmental benefits to local communities.

Having outlined the state of current literature regarding slow tourism and cycle tourism as one form of the former, this paper now aims to understand whether the general principles that have been identified in the literature apply to the Italian case, where cycle tourism started to develop only recently. Even if cycle tourism is a promising opportunity in Italy, the country of interest in this analysis is running late on this development [118,119]. In Italy in 2014, according to Sole 24 Ore, the number of cycle tourists was 2.3 million, or $64 \%$ foreign tourists (July 2015). There has been an increase in comparison with previous years, and although there is a delay in the development of cycle tourism 
and the image of cycle tourism is linked strongly to sport, it is possible to identify some opportunities to expand this relatively new form of tourism [79]. In northern Italy, especially in the mountain areas, although the offer is still fragmented, some regions are transforming their offers to meet the request of this growing segment [120]. Therefore, this paper aims to understand how these cases developed (including drivers for this development) and whether there are any differences in the development of cycle tourism in the country. In particular, we questioned whether there is only one successful strategy for achieving this goal or whether it is possible to achieve the goal through different strategic decisions (RQ1). Additionally, the research aimed to understand the role of little-known or remote territories in cycle tourism development (RQ2). This was explored to have a clearer picture of whether or not the existence of a little-known or remote territory was a crucial factor for developing such a form of tourism.

This will be explored by analyzing the peculiarity of Italian destinations where the concept of development in little-known or remote territories and cycle tourism has been implemented and where cycle tourism has been considered as a driver for their tourism development purposes.

\section{Materials and Methods}

\subsection{Methods}

For this research, the case studies methodology was used [121,122]. This methodology is applied in social science and in practice-oriented fields, such as environmental studies, social work, education, and business studies. Research findings produced by case studies can be useful for the comprehension of a specific question and can add elements to underline arguments from previous studies. A case study can improve our understanding of a specific context or relation between events. The aim of this paper is to explore what drives the development of cycle tourism to understand, by focusing on precise realities, the path of cycle tourism in Italy. For a destination could be implemented a strategy to increase its competitiveness, attractiveness and profitability and the involved stakeholder benefits in order, also, to reinforce the rejuvenation process. To explore the topic, we took into consideration two main research questions.

To collect evidence useful for the research, we selected three different destinations in sensitive mountain areas in the north of Italy. These three regions, which converge on the common goal of using cycling to rejuvenate and reinvigorate their tourism sectors, are Varese (mountain area of the Alps), Regione Liguria (mountain area of the Apennines), and Colli di Coppi (hilly area near Apennines). Although these areas are different in terms of geographical characteristics and the business models used for destination development and management, they share a common willingness to develop cycle tourism.

\subsection{Materials: The Cases}

In the following section, we present the main characteristics of the selected cases.

\subsubsection{Lombardy-Varese}

The province of Varese is located at the foot of the Alps in the north of Lombardy. Its territory is composed of $32 \%$ mountains and $46 \%$ hills; there are also numerous rivers and lakes (e.g., Lake Maggiore and Lake Ceresio) that are interspersed with many valleys (among the most important of these are the Olona Valley, the Valceresio, and the Valganna).

This territory is considered a destination where tourism is developed based on the natural and cultural resources and where cycle tourism is one of the main niche markets in which local stakeholders have invested. There is already a product club in Varese. It was created using a bottom-up approach developed by private initiative. The Varese product club, called Lake Maggiore Bike Hotels, aims to develop a network of relationships dedicated to creating a "cycle-friendly environment" that will transform the province of Varese into a cycling destination. The club provides new kinds of services 
such as guides, rental equipment, and logistics: products and services that tourists that visit the area need. The product club is an initiative that should increase the connection between institutions, organizers, hotels, and all the commercial activities that could be involved in the tourism supply chain. To allow for the development of the product club in this territory, there is a strong synergy between some local authorities, such as the Chamber of Commerce of Varese, the Federalberghi Varese, and the Regione Lombardia, and the accommodation facilities and food and beverage outlets that are part of the territory.

The analysis includes both secondary data (reports, webpages, social media pages, articles, printed tourism information, etc.) and primary data (interviews). Data were collected from the Lombardy Region, Varese, and other municipalities, the Varese Chamber of Commerce, Agenzia Nazionale del Turismo (Enit), Varese Land of Tourism, product club companies' (8 hotels) official reports, webpages, social media pages, and more. Interviews were conducted with hotels representatives, the product club manager, and a Varese Land of Tourism representative.

\subsubsection{Liguria Region}

The region is between the Ligurian Alps and the Ligurian Apennines to the north and the Ligurian Sea to the south, with a broken chain that is a real backbone that continues throughout the territory. Liguria is a land rich in natural beauty in which the combination of land and sea makes the variety of ecosystems particularly heterogeneous, and the " 5 Terre" national park is also located within this territory.

This second case was selected because here it is a local authority that wants to use a top-down approach to an infrastructure that can drive this territory to become a cycling destination. This could be an interesting zone that could develop quickly due to its proximity to the great Italian (BiciTalia) and European (EuroVelo) cycling networks. In this region, we found a hierarchical structure. Additionally, no product clubs have been created yet, and it is still at an ideal status in comparison to other realities.

The analysis includes official information provided by the Liguria Region, secondary data (reports, webpages, social media pages, articles, etc.), and primary data collected through interviews with the Ligura Region representatives.

\subsubsection{Piedimont-“Colli di Coppi”}

The third example was selected because the development of cycle tourism here is linked to a bottom-up approach driven by a non-profit organization rather than private companies. Located at the crossroads of four regions, in the northwest of Italy, much of this territory remains largely unknown, making it a ripe region for explorers. The hills near Tortona present themselves as a complex and varied landscape in which the beauty of a wild and uncontaminated nature is the backdrop to places where small country roads, parish churches, fields, and green woods are the emblem of an evolving world. The territory is considered one of great charm and tradition [123]. Here, tourists can enjoy high-quality local products in beautiful natural environments [124] by cycling on well-known roads used by important cyclists of the past [125]. This is an example of a good implementation of local control. In fact, they have organized "informal meetings", called cafés, where local participants exchange views on all aspects of the project (sports, gastronomic, political, and technical) and receive a clear view of the process, including its future and possible problems. The first output of this organization is a sporting event called La Mitica. This race is an event in memory of the Coppi Brothers that promotes "slow" (non-competitive) cycling, representing the pillars of sustainable tourism by allowing the cycle tourists to find mental and physical balance as they enjoy rural features and local products.

The analysis includes secondary data (reports, webpages, social media pages, articles, printed tourism information, etc.) and primary data (interviews). The following sources provided information: Gal Giarolo Leader, municipalities (56), Piedmont Region, Alessandria Province DMO (Alexala), Alessandria Chamber of Commerce, Agenzia Nazionale del Turismo (Enit), consortium of mountain 
municipalities' official report, webpages, and social media pages. Interviews were conducted with the municipalities' majors.

The results presented in this paper are based on a qualitative research approach, using interpretivism, and aimed at understanding the phenomena that are behind the developments described above [126]. Primary and secondary data relevant to the three selected cases were thoroughly investigated, and the instrument of semi-structured interviews was used as a primary data collection tool [127-129]. Representatives from local authorities, local restaurants, hotels, and tourism offices were interviewed to collect primary data regarding local cycle tourism practices. Open and probing questions were used to encourage the interviewees to express his/her opinion and solicit a richer and more accurate response, as well as to reduce the amount of irrelevant information. The interviews were semi-structured; however, free form questions were also used according to the flow of the conversation [129]. The questions used in the interviews were designed to investigate the contributions of cycle tourism to the development of sustainable tourism and destination development, as well as to understand the factors that influence the development of cycle tourism, including the economic, social, and environmental dimensions. Interviews were conducted with local stakeholders, including hotel managers, politicians (at local, provincial, and regional levels), members of associations, and other potential stakeholders who could affect and be affected by the development of cycle tourism. In addition to collecting evidence by interviewing these representatives, local newspaper and magazine articles (both online and offline) about such development initiatives were also analyzed to gather further evidence. Interviews were transcribed verbatim. Interviews and articles were analyzed according to the content analysis approach.

Using a content analysis approach [130], data were analysed to find development traits in order to identify a common path of development. From the analysis, common characteristics for sustainable tourism development were identified [130], allowing us to glean more in-depth insights. Nvivo was the software selected to support the analysis.

\section{Results}

The analysis of the data collected enabled further understanding of the role of cycle tourism as a strategic asset for environmental protection, socio-cultural protection, and economic development. For simplicity, the results of this analysis are broken down into the following three categories: environmental, social, and economic. Each is discussed in Sections 3.1-3.3. Thus, our research found evidence of common strategic principles for the development of cycle tourism, including emphasizing the role of little-known or remote territories and their characteristics. There are currently 12 accepted pillars or principles of sustainable tourism development, and these were used to guide our data collection [129]. The 12 principles are as follows: physical integrity, biological diversity, resource efficiency, environmental purity, cultural richness, community wellbeing, local control, visitor fulfilment, social equity, employment quality, local prosperity, and economic feasibility. The principles we were able to identify in the specific cases under investigation here are physical integrity (PI), biological diversity (PD), resource efficiency (RE), cultural richness (CR), local control (LC), community wellbeing (CW), social equity (SE), visitor fulfilment (VF), and local prosperity (LP).

For each dimension, the current situation and future development actions are taken into consideration by looking at Lombardy, Liguria and Piedmont examples. Once these aspects have been identified, analysis on the assets, resources, features and projects has been provided to identify common drivers for this development.

\subsection{Environmental Dimension}

Table 1 summarizes the main findings of our research with reference to the environmental drivers. As is clear from information collected about the environmental dimension in each of the regions we studied, the development of cycle tourism might have been inspired by principles of environmental sustainability and environmental friendliness. In the area of Varese, the strong bond between the 
environment's richness and cycle tourism is visible: the main cycle route around the lake allows people to cycle close to the lake and enjoy its fauna and flora. In the case of the Liguria Region, cycle tourism enables visitors to encounter restored architectural beauty as part of the landscape of the cycling experience. In Piedmont, environmental conservation enables the maintenance of biodiversity, and this is supported because the environmental resources are those tangible elements that matter for the development of such a tourism offer. This implies that it might be possible develop cycle tourism without exploiting local resources and endangering the environment, because these are the primary sources for cycle tourism success. Cycle tourists seems to be interested in cycling in unspoiled environments that are far away from polluted areas and offer interactions with nature and its biodiversity. They travel in a way that is sustainable, and they also expect sustainability when it comes to the environments they choose to enjoy. A lack of environmental resources or behaviours that compromise them make cycle tourism difficult to develop. In these areas, the existence of uncontaminated environmental resources becomes a common driver for the development of cycle tourism.

Table 1. Environmental Dimension.

\begin{tabular}{|c|c|c|c|}
\hline Region & Lombardy-Varese & Liguria Region & Piedimont—“Colli di Coppi" \\
\hline $\begin{array}{l}\text { Current situation } \\
\text { and future } \\
\text { development }\end{array}$ & $\begin{array}{l}\text { Environmental } \\
\text { sustainability } \\
\text { and friendliness. } \\
\text { - Strong bond between } \\
\text { the environment and } \\
\text { cycle tourism. }\end{array}$ & $\begin{array}{l}\text { - Local richness in } \\
\text { environmental resources. } \\
\text { Willingness to reuse existing } \\
\text { resources, such as recovery of } \\
\text { abandoned railways on the } \\
\text { seaside and on the hills and } \\
\text { mountains. (RE, PI) }\end{array}$ & $\begin{array}{l}\text { - } \quad \text { Role of the environment as an } \\
\text { enviable element for success. } \\
\text { Willingness to develop actions that are } \\
\text { environmentally sustainable. } \\
\text { - Strong bond between the territory and } \\
\text { its environmental dimension. } \\
\text { - Food and wine tourism developed in } \\
\text { connection with the landscape. (BP) }\end{array}$ \\
\hline $\begin{array}{l}\text { Assets, resources, } \\
\text { features, and } \\
\text { projects }\end{array}$ & $\begin{array}{l}\text { Product club players } \\
\text { that offer hospitality by } \\
\text { developing innovative } \\
\text { and sustainable } \\
\text { projects (e.g., Albergo } \\
\text { Diffuso) }{ }^{*} \text { (LC). } \\
\text { Architectural } \\
\text { monuments and a } \\
\text { series of natural } \\
\text { resources (lake, } \\
\text { mountains, etc.) (CR). }\end{array}$ & $\begin{array}{l}\text { - The sea area is well known and } \\
\text { well developed and publicized, } \\
\text { and it is a driver for the } \\
\text { development of tourism in the } \\
\text { hinterland, where interesting } \\
\text { villages with a strong cultural } \\
\text { richness are present (CR). } \\
\text { Alternative activities due to } \\
\text { the proximity of the sea and } \\
\text { the hills/mountains provide a } \\
\text { broader portfolio for potential } \\
\text { customers. (VF) }\end{array}$ & $\begin{array}{l}\text { - Hills with complex and varied } \\
\text { landscapes where the beauty of a wild } \\
\text { and untouched nature is the backdrop } \\
\text { to human habitats. } \\
\text { - } \quad \text { Archaeological and architectural } \\
\text { heritage (CR). } \\
\text { - } \quad \text { Beautiful landscapes (PI). } \\
\text { - } \quad \text { Rural area with limited } \\
\text { - } \quad \text { Limited infrastructure (PI). }\end{array}$ \\
\hline
\end{tabular}

* a project developed under the restoration of the environment [131].

\subsection{Social Dimension}

Similar findings have been identified for the social dimension (as mentioned in Table 2). Social characteristics, especially cultural richness and local governmental control, might be essential for developing cycle tourism initiatives.

In the cases studied here, the social dimension played an important role in shaping the development of cycle tourism. The presence of heritage and cultural sites that are strongly linked with the local community were a strong driver for the development of cycle tourism in these areas. As with the environmental dimension, our findings regarding the social dimension are in line with the findings of previous literature in the field in that all have suggested the powerful role that environmental and social politics play in the development of this niche form of tourism. The fact that some aspects of the cultural richness have not been valued in the past can allow to start from an unspoiled destination, avoiding the need of investing in projects of recovery of unsustainable tourism development practices. The unspoiled cultural richness becomes an element to protect by developing sustainable tourism practices that enable this beauty to be experienced without being exploited. One way to achieve 
such protection is by regulating the development as suggested by [132]. In this scenario, we need to recognize the role that government plays in local development. Indeed, in the case study examples reviewed here, cycle tourism has been driven by initiatives developed by local authorities or private stakeholders who are interested in developing local, sustainable tourism with input from a variety of stakeholders. Moreover, the concept of "coopetition" [133] is one driver of development identified in each of the different scenarios, where different stakeholders, including competitors, decide to cooperate to enable the development of cycle tourism in a way that empowers local communities.

Table 2. Social Dimension.

\begin{tabular}{|c|c|c|c|}
\hline Region & Lombardy-Varese & Liguria Region & Piedimont-"Colli di Coppi" \\
\hline $\begin{array}{l}\text { Current } \\
\text { situation and } \\
\text { future } \\
\text { development }\end{array}$ & $\begin{array}{l}\text { - Several potential cultural } \\
\text { attractions (CR) } \\
\text { Cultural richness that boosts } \\
\text { heritage and cultural } \\
\text { opportunities. (CR) } \\
\text { - } \quad \text { Local control (LC) } \\
\text { Increasing number of } \\
\text { tourism-related initiatives, } \\
\text { including cycle tourism, are } \\
\text { increasing the attention paid } \\
\text { to them, although the } \\
\text { destination is still at is } \\
\text { embryonic level in terms of } \\
\text { tourism. development. (VF) }\end{array}$ & $\begin{array}{l}\text { - Neglected cultural richness that } \\
\text { could boost the development of } \\
\text { alternative forms of tourism that } \\
\text { cycle tourists are looking for. } \\
\text { (CR) } \\
\text { Development of a network of } \\
\text { safe routes for cyclists. (LC) }\end{array}$ & $\begin{array}{l}\text { - } \\
\text { - } \quad \text { fostivals, unrelated to each other. (CR) } \\
\text { cyclo-tourist event run in the hills, } \\
\text { with participants (non-professionals) } \\
\text { biking on vintage bikes. It is a race for } \\
\text { a few cyclists who meet for one day to } \\
\text { cycle in honor of Coppi's legend. The } \\
\text { legend of this race attracts several } \\
\text { tourists every year who choose to } \\
\text { cycle this route. (CR) } \\
\text { Low perception of the utility of } \\
\text { tourism as a driver of } \\
\text { economic development. }\end{array}$ \\
\hline $\begin{array}{l}\text { Assets, } \\
\text { resources, } \\
\text { features, and } \\
\text { projects for } \\
\text { development }\end{array}$ & $\begin{array}{l}\text { Bottom-up willingness to } \\
\text { develop sustainable tourism. } \\
\text { (LC) } \\
\text { This aim was partially } \\
\text { achieved with the creation of } \\
\text { a product club. (LC) } \\
\text { - Strong synergy between } \\
\text { some local authorities, } \\
\text { unions, and hotel facilities, } \\
\text { showing significant } \\
\text { opportunities for local } \\
\text { control. (LC) }\end{array}$ & $\begin{array}{l}\text { - Top-down willingness to } \\
\text { develop sustainable tourism. } \\
\text { Policies to support the } \\
\text { development of cycle tourism } \\
\text { and invest resources in a } \\
\text { rational way. } \\
\text { - Creation of a regional bike } \\
\text { network that is integrated with } \\
\text { the Italian and European } \\
\text { cycling scheme. } \\
\text { Government plays an important } \\
\text { role in the development of } \\
\text { cycle tourism. } \\
\text { Embryonic stage of the creation } \\
\text { of a product club, which is } \\
\text { currently seeking proactively to } \\
\text { gather and synergise all of the } \\
\text { public, private, and institutional } \\
\text { stakeholders. (LC) }\end{array}$ & $\begin{array}{l}\text { Bottom-up willingness to develop } \\
\text { sustainable tourism. (LC) } \\
\text { Informal product club developed } \\
\text { through local government initiative, in } \\
\text { this case the Province of Alessandria } \\
\text { and some municipalities. (LC) } \\
\text { Private stakeholder in biking and } \\
\text { gastronomic companies willing to } \\
\text { influence/control the decision-making } \\
\text { process at destination level. (LC) } \\
\text { Promote the principles of coopetition } \\
\text { to develop cycle tourism. (LC) }\end{array}$ \\
\hline
\end{tabular}

\subsection{Economic Dimension}

Finally, another dimension driving the development of cycle tourism is the economic viability of the projects and the employment opportunities they generate (as mentioned in Table 3). In all three of our case study examples, it might be clear that, previously, tourism was not considered to be much of an economic driver (with the exception of the seaside in Liguria). Thus, the tourism developing in these regions now is unhindered by earlier tourist ideologies and can more readily be aligned with the principles of sustainable tourism that were previously introduced. Furthermore, this development requires fewer allocations of resources than those required to turn an unsustainable tourism destination into a sustainable one. If well developed, cycle tourism will create new job opportunities that will increase tourists' satisfaction and reduce the problem of seasonality.

\section{Economic Data}

The Province of Varese, from a general tourist point of view, saw a positive increase in tourism from 2006 to 2016 with $+2.1 \%$ tourist arrivals. In the last year for which information is available (2016), more than 27,000 more tourists registered than in 2015, for a total of 1,302,647 arrivals [134]. Liguria registered 15,551,000 tourists in 2017, about half a million more than in 2016. This represents a 3\% 
increase in attendance and a 5\% increase in arrivals. The increase in entrance fee compared to 2016 is $+1.34 \%$. Genoa recorded an increase of $3.21 \%$, for a total of about 4.1 million tourists, while Imperia $(+3.31 \%)$ recorded over 3.2 million admissions, which is 103,000 more than the previous year [135]. The data related to the Ligurian territory are very encouraging. The number of tourists as well as the number of overnight stays by tourists coming from European countries is increasing; in 2016, the number reached 1,765,850 arrivals, almost 100,000 of which were cycle tourists [136].

Table 3. Economic Dimension.

\begin{tabular}{|c|c|c|c|}
\hline Region & Lombardy-Varese & Liguria Region & Piedimont-"Colli di Coppi" \\
\hline $\begin{array}{l}\text { Current } \\
\text { situation and } \\
\text { future } \\
\text { development }\end{array}$ & $\begin{array}{ll}\text { - } & \text { Cycle tourism allows for } \\
\text { - } & \text { seasonal adjustment. (EF, LP) } \\
\text { to improve customer satisfaction. } \\
\text { (EQ, CW, SE) } \\
\text { - } \quad \text { Grow the tourism industry. (LP) } \\
\text { Increase in foreign tourists } \\
\text { visiting the area with much more } \\
\text { interest in sustainable practices. } \\
\text { (VF) } \\
\text { Sustainably develop tourism as a } \\
\text { new strategic asset for the } \\
\text { territory (Varese was historically } \\
\text { a manufacturing area). (LP) }\end{array}$ & $\begin{array}{l}\text { Tourism (more developed on the } \\
\text { seaside) is one of the primary } \\
\text { activities, although it is not } \\
\text { focused on cycle tourism. } \\
\text { (EF, LP) } \\
\text { - Sea, hills, and mountains all in } \\
\text { one territory enable the creation } \\
\text { of alternative tourism } \\
\text { opportunities that attract cycle } \\
\text { tourists. (VF) } \\
\text { New jobs to ensure visitor } \\
\text { satisfaction are created thanks to } \\
\text { cycle tourism. (LP, EQ, CW, SE) } \\
\text { Tourists are encouraged to } \\
\text { experience Liguria's beauty far } \\
\text { from the sea thanks to cycle } \\
\text { tourism. (VF) }\end{array}$ & $\begin{array}{l}\text { Tourism based on sport } \\
\text { events. (CR) } \\
\text { Tourism not seen as } \\
\text { primary activity for } \\
\text { economic development; } \\
\text { however, tourism could } \\
\text { improve the local economy } \\
\text { (mainly based on industry } \\
\text { and agriculture) with new } \\
\text { job profiles. (EQ, CW, SE, } \\
\text { EF, LP) }\end{array}$ \\
\hline $\begin{array}{l}\text { Development } \\
\text { assets, } \\
\text { resources, } \\
\text { features, and } \\
\text { projects }\end{array}$ & $\begin{array}{l}\text { New job opportunities, such as } \\
\text { cycling guides and mobility } \\
\text { manager, have been created } \\
\text { thanks to cycle tourism. (EQ, } \\
\text { CW, SE) } \\
\text { New roles important to ensure } \\
\text { visitor satisfaction. (EQ, CW, } \\
\text { SE, VF) }\end{array}$ & $\begin{array}{l}\text { The creation of new job profiles, } \\
\text { such as cycling guides and the } \\
\text { mobility manager, linked to } \\
\text { cycle tourism. (EQ, CW, SE) }\end{array}$ & $\begin{array}{l}\text { Embryonic tourism } \\
\text { development (EF) } \\
\text { Lower level of seasonality. } \\
\text { (EF) } \\
\text { - New professional figures } \\
\text { have been created, such as } \\
\text { those created by the } \\
\text { "sports" events. (EQ, } \\
\text { CW, SE) }\end{array}$ \\
\hline
\end{tabular}

\section{Discussion and Conclusions}

\subsection{Research Contribution and Originality: Theoretical and Practical Implications}

The findings allow us to conclude that the development of cycle tourism thus far has been rooted in the development of projects that are economically viable while simultaneously promoting the creation of new job profiles that will contribute to an increase in employment in those destinations where cycle tourism is sustainably developed. Cycle tourism represents almost $12 \%$ of Italy's GDP. Cycle tourism has proven to be a seasonally adjusted tourist activity that is practiced for $70 \%$ of the year and is eco-sustainable. In Italy, it has a potential value of 3.2 billion $€$, and it is growing at a constant rate $[137,138]$.

Within the framework of sustainable tourism, which is a well-established trend in industrialized countries, cycling tourism offers tourists the opportunity to explore and discover little-known areas that are often located in mountains or in geographical areas with different characteristics, such as the "Loire à Vélo" in France near the castles of the Loire Region or the "Ecovia Litoral" in Algarve. As emerged from the cases studies, the role of territory is directly linked to the concept of slow tourism might be a fundamental element for the development of cycle tourism. This gives further evidence regarding the role of little-known or remote territories in cycle tourism development as per RQ2. Little-known or remote territories are in a position to create the extraordinary experiences that cycle tourers are looking for. It is a form of strong experiential value tourism, which provides direct contact with a territory-its culture, history, and traditions—at a speed that can be defined on a human scale [139]. From this point 
of view, cycling could be considered a form of slow tourism that allows visitors to enjoy and preserve the environment simultaneously, which is the main attraction of cycling as an activity. As with other sports often related to nature, cycling is well suited to little-known or remote areas, where people tend to celebrate quality landscapes, agricultural excellence, and local culture and traditions [140]. Attention to local tourist supply details, not just to the bike path in the strict sense, highlight the desire for this type of tourist to "live" the travel experience that captures the territory in its entirety. From this perspective, cycle tourism promotes an experience of mutual learning between cyclist and land, a sharing of values ingrained in the history and traditions, as well as a real possibility of protecting biodiversity and promoting sustainable forms of development $[100,140]$. The characteristics of cycling make it a mode of sustainable tourism, as it shares the social, environmental, and economic values that characterize sustainable tourism. In light of these considerations, it seems undeniable that, if properly managed, cycling can become an important tool for territorial marketing and local development. Territories that choose to present themselves to cyclists must commit to a "product" that is attractive and includes several products and services (guide tours, cycling shops, accommodations, F\&B outlets, retail shops, etc.). In this sense, marketing plays a central role in the strategy, where it should facilitate the construction of territorial offers capable of meeting the expectations of the subjects that the territory is interested in attracting, which may vary based on the model of sustainable development they are pursuing [141-143]. More specifically, an articulate elaboration of a marketing strategy aimed at the development of cycling in view of land development involves the following key steps: defining the mix of structural features and services offered from the area; identifying an appropriate system of incentives for existing and potential users of the services and facilities offered by the area; identifying effective methods for distributing the territory's services and products; promoting the image of the area in such a way that potential visitors perceive its intrinsic value. In this context, it is crucial to offer tourists the chance to come in contact with a natural environment and local culture that include products, events, traditions, economic activities, and more through a network of cycling routes that facilitate the movement called "slow". Crucial to this end is the establishment of a planning team comprised of public and private stakeholders within the territory-a sort of control room-with well-defined strategic tasks, including the following:

- $\quad$ analysis of the reference features to highlight success factors and critical issues;

- creation of a long-term strategy, built from resources and opportunities in the territory; and

- development of an action plan, divided into intermediate steps, indicating the investments and actions needed to achieve its goals.

The long-term orientation is needed because interventions on most of the factors characterizing the territorial offer require at least a medium-term period of time to complete. This aspect emphasizes the importance of public-private partnership [144]. The cases presented in this study show that the development of cycle tourism is linked to the presence and/or construction of several elements that could be defined as "facilitators", some of which are intrinsic to the territory (such as environmental resources) and others that are effects of territorial policies (such as social and economic dimensions). In particular, the ability to capitalize on the potential offered by cycle tourism requires the presence of a network of local actors, both public and private, which act synergistically toward the success of the initiative. At a policy level, this implies the need to develop all projects in an integrated way, involving all the stakeholders in the territory. The three different but successful experiences analyzed in this study show that the expansion of cycle tourism needs to be supported by original forms of public-private partnerships that are oriented toward building innovative and advanced forms of offers that combine entrepreneurial private interests with public development goals. From the cases analyzed here, it is clear that there are many possibilities for implementing the development of a successful cycle tourism reality, and there is more than one possible strategy to follow (RQ1). The aim was to gain further insights into the role of strategy in destinations willing to develop cycle tourism experiences and understand whether there was only one successful strategy for achieving this goal or if different 
strategic decisions could produce success. With this research we were able to confirm that there is more than one possible strategy to develop cycle tourism in little-known or remote territories. However, the different strategies have something in common. The cases presented in this study highlight that only by overcoming the fragmentation of interventions and coordination of the different actions. Moreover, the streets for cycling tourism can become an important driving force for the development of areas far from main roads of mass tourism but rich in excellence and potential, activating a virtuous circle between public and private actors. The factor that is essential to success in this regard is the ability to structure a comprehensive and complete system for creating and enhancing cycling networks that overcomes administrative and territorial boundaries through shared activities and a coordinated effort. This implies that any successful cycling project has developed an integrated approach, involving all the stakeholders through a unified strategic design.

The findings are summarized also in Figure 1.

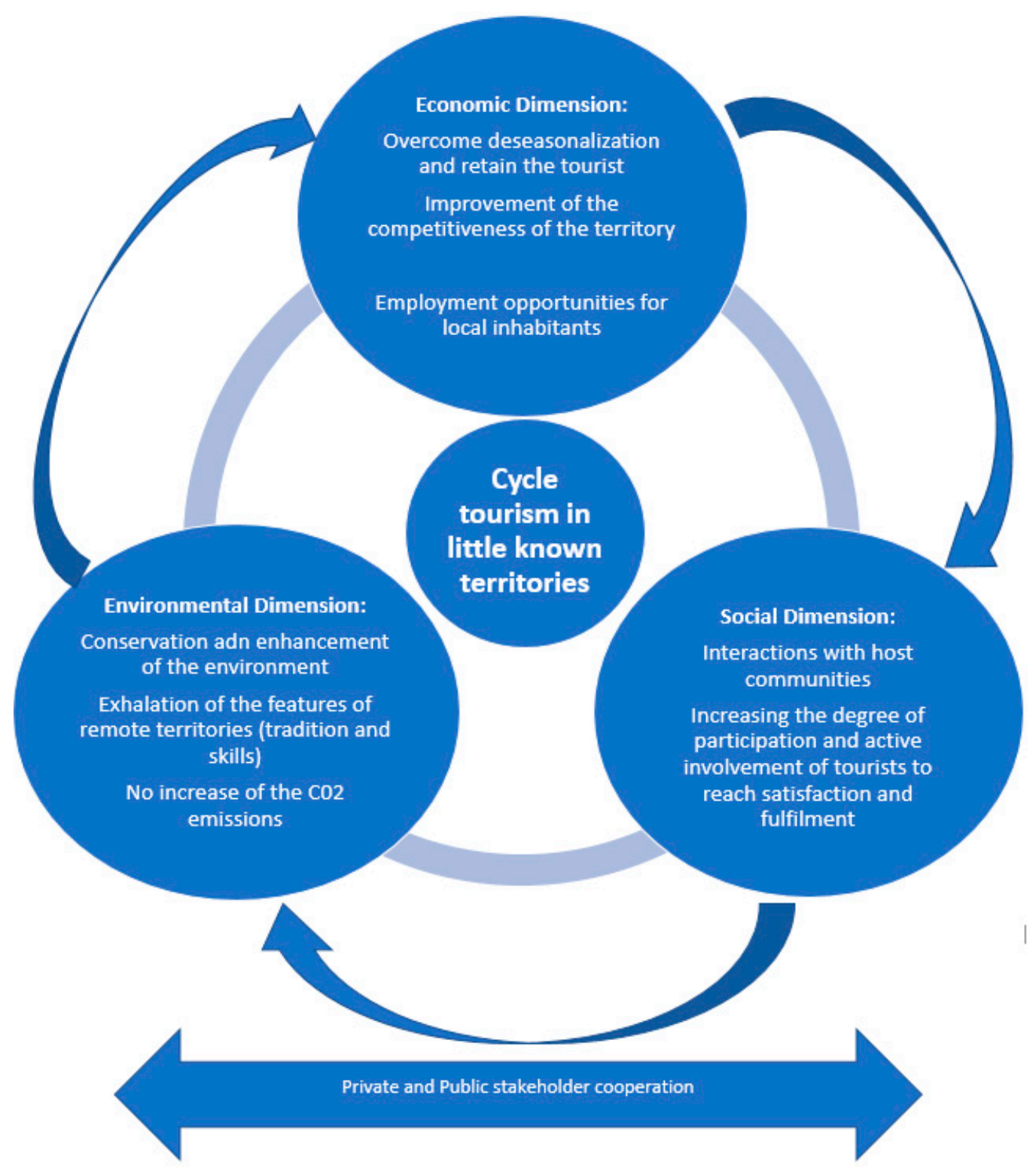

Figure 1. Findings. 


\subsection{Conclusions}

To allow cycle tourism to develop as a driver for sustainable tourism, it is important to improve the availability of other forms of sustainable tourism transportation to enable tourists to get to the destinations from where they depart for their cycle holidays (within this paper, we considered cycle holidays characterized by tourists arriving at destinations via other modes of transportation and then using cycling as a way to explore the destination area). To this end, the three destinations considered here are well served by trains (in particular electric ones), which is one of the less polluting modes of transportation in terms of $\mathrm{CO}_{2}$ emissions [145]. Fulfilment of this condition makes cycle tourism much more sustainable than other types of tourism. However, cycle tourists might arrive at their departure destinations by plane or car (they do not use the car while on holiday), depending on their origin region. This could be a challenge for deeply developing sustainable tourism, as it is already a problem that other forms of tourism have experienced. Although this is a potential challenge, it is also important to remember that cycle tourists at least cycle between destinations, reducing their carbon footprint over the course of the cycling holiday. These initiatives might have only site-specific results and local focus, but it is a starting point for further development, as per Weaver [146].

As previously stated, it is worth highlighting that these three destinations followed the aim to become a cyclist sustainable tourism destination using different strategies (RQ1). Potential economic impacts are another aspect to consider. Cycle tourism development could be a driver for more general tourism development that is aligned with the principles of slow tourism. In such a circumstance, the economic development occurs slowly, in line with the territory, in order to eschew short-term profits in favour of uncompromised long-term results; the principle for development must be aligned with the concept that small is beautiful. These destinations are, at the moment, circumstantial alternative tourism (this is an advantage for the destinations since they could develop sustainable since the beginning of their development cycle) destination. Understanding the role of remote territories in cycle tourism development (RQ2) is important and relevant because these destinations can prosper through the presence of alternative tourists who prefer these kinds of little-known territories instead of classical mass holidays.

\subsection{Limitations and Future Research Directions}

Cycle tourism in Italy is a relatively emergent phenomenon that requires further understanding to identify how it develops, the appropriate applicable business models, and the link with sustainable practices. This paper reveals valuable insights that can inform the development of cycle tourism in different areas, as well as having important implications for both policymakers and entrepreneurs. Despite its contributions, this paper does have some limitations. This analysis aims to be illustrative rather than exhaustive or definitive. The first limits of this research are the limited research sample and limited coverage area. To further advance the field, future research should include inquiries into other little-known or remote territories that have decided to develop this type of sustainable tourism, particularly their strategies in terms of the actors involved and the role of local governments. The definition of cycle tourism is focused only on those tourists who cycle from one destination to another, which does not include spectators. This definition aligns with the goal set in these territories to develop cycle tourism in line with slow tourism characteristics and a focus on cycle holidays. This limits the findings to this type of territory, and it neglects broader cycle tourism developments that apply a wider definition of cycle tourism that also includes spectators and excursionists. Another interesting research opportunity concerns the long-term observation of the three territories examined here to see what results are produced by the cycle tourism development strategies currently in place. Finally, a more in-depth analysis of the structural factors of the territories examined could be useful for delineating the links between the intrinsic characteristics of a territory and possible strategies for developing forms of sustainable tourism. 
Author Contributions: P.G., E.P., D.G. and P.O. reviewed the literature, analyzed the case and discussed the implications of the results all together.

Funding: This research received no external funding.

Conflicts of Interest: The authors declare no conflict of interest.

\section{References}

1. Gazzola, P.; Colombo, G.; Pezzetti, R.; Nicolescu, L. Consumer empowerment in the digital economy: Availing sustainable purchasing decisions. Sustainability 2017, 9, 693. [CrossRef]

2. Andereck, K.L. Tourists' perceptions of environmentally responsible innovations at tourism businesses. J. Sustain. Tour. 2009, 17, 489-499. [CrossRef]

3. Caruana, R.; Glozer, S.; Crane, A.; McCabe, S. Tourists' accounts of responsible tourism. Ann. Tour. Res. 2014, 46, 115-129. [CrossRef]

4. Donohoe, H.M.; Needham, R.D. Ecotourism: The evolving contemporary definition. J. Ecotour. 2006, 5, 192-210. [CrossRef]

5. Karanikola, P.; Panagopoulos, T.; Tampakis, S.; Tsantopoulos, G. Cycling as a Smart and Green Mode of Transport in Small Touristic Cities. Sustainability 2018, 10, 268. [CrossRef]

6. Chafe, Z.; Honey, M. Consumer Demand and Operator Support for Socially and Environmentally Responsible Tourism; Center on Ecotourism and Sustainable Development: Washington, DC, USA, 2005. Available online: http:/ / efti.hhp.ufl.edu/wp-content\%5Cuploads/Consumer-Demand-for-ResponsibleTourism-2005.pdf (accessed on 26 February 2018).

7. Franch, M.; Sambri, C.; Martini, U.; Pegan, G.; Rizzi, G. La domanda di turismo responsabile e di eco-turismo in Italia. Un'indagine esplorativa sui turisti CTS. In Proceedings of the 7th International Conference Marketing Trend, Venice, Italy, 17-19 January 2008; pp. 1-21.

8. Breakey, N.M.; Breakey, H.E. Tourism and Aldo Leopold's "cultural harvest": Creating virtuous tourists as agents of sustainability. J. Sustain. Tour. 2015, 23, 85-103. [CrossRef]

9. Pencarelli, T.; Forlani, F. Il marketing dei distretti turistici-sistemi vitali nell'economia delle esperienze. Sinerg. Riv. Studi Ric. 2011, 58, 231-277.

10. Dwyer, L.; Kim, C. Destination competitiveness: Determinants and indicators. Curr. Issues Tour. 2003, 6, 369-414. [CrossRef]

11. Keller, P.; Bieger, T. (Eds.) Real Estate and Destination Development in Tourism: Successful Strategies and Instruments; Erich Schmidt Verlag GmbH \& Co. KG: Berlin, Germany, 2008; Volume 3.

12. Bieger, T. Destination Management e Finanziamenti; Pechlaner, H., Weiermair, K., Eds.; T.U.P Touring Editore: Milan, Italy, 2000.

13. Manente, M.; Cerato, M. (Eds.) From Destination to Destination Marketing and Management: Designing and Repositioning Tourism Products; Libreria Editrice Cafoscarina: Venezia, Italy, 2000.

14. Boari, C.; Grandi, A.; Lorenzoni, G. Le organizzazioni a rete: Tre concetti di base. Econ. Politica Ind. 1989, 64, 283-310.

15. Crompton, J.L. Motivations for pleasure vacation. Ann. Tour. Res. 1979, 6, 408-424. [CrossRef]

16. Dann, G.M. Anomie, ego-enhancement and tourism. Ann. Tour. Res. 1977, 4, 184-194. [CrossRef]

17. Sen, A. Development as Freedom; Oxford Paperbacks; Clarendon Press: Oxford, UK, 2001.

18. Richins, H. Environmental, cultural, economic and socio-community sustainability: A framework for sustainable tourism in resort destinations. Environ. Dev. Sustain. 2009, 11, 785-800. [CrossRef]

19. Pilotti, L.; Apa, R.; Tedeschi-Toschi, A.; Sarman, I. La competitività dinamica degli ecosistemi territoriali. Il caso degli eco-sistemi turistici multilocali tra Italia e Svizzera. In Proceedings of the Atti del XXIV Convegno Annuale di Sinergie, Lecce, Italy, 18-19 October 2012.

20. Demirović, D.; Radovanović, M.; Petrović, M.D.; Cimbaljević, M.; Vuksanović, N.; Vuković, D.B. Environmental and Community Stability of a Mountain Destination: An Analysis of Residents' Perception. Sustainability 2017, 10, 70. [CrossRef]

21. Reisinger, Y.; Dimanche, F. International Tourism; Routledge: London, UK, 2010.

22. Crouch, G.I.; Ritchie, J.B. Tourism, competitiveness, and societal prosperity. J. Bus. Res. 1999, 44, 137-152. [CrossRef] 
23. Kaltenborn, B.P.; Williams, D.R. The meaning of place: Attachments to Femundsmarka National Park, Norway, among tourists and locals. Nor. Geogr. Tidsskr. 2002, 56, 189-198. [CrossRef]

24. Gross, M.J.; Brown, G. Tourism experiences in a lifestyle destination setting: The roles of involvement and place attachment. J. Bus. Res. 2006, 59, 696-700. [CrossRef]

25. Pavione, E.; Pezzetti, R.; Gazzola, P. The Role of "Slow Territories" in the Development of Sustainable Tourism. Eur. Sci. J. 2017, 13, 238-248.

26. Lancerini, E. Territori Lenti: Contributi per una Nuova Geografia dei Paesaggi Abitati Italiani; Territorio; Franco Angeli: Milan, Italy, 2005.

27. Folorunso Adeyinka-Ojo, S.; Khoo-Lattimore, C. Slow food events as a high yield strategy for rural tourism destinations: The case of Bario, Sarawak. Worldw. Hosp. Tour. Themes 2013, 5, 353-364. [CrossRef]

28. Richins, H.; Hull, J. (Eds.) Mountain Tourism: Experiences, Communities, Environments and Sustainable Futures; CABI: Wallingford, UK, 2016.

29. Grechi, D.; Ossola, P.; Pavione, E. Expo 2015 and Development of Slow Tourism: Are the Tourism Product Clubs in the Territory of Varese Successful? In Proceedings of the Toulon-Verona Conference" Excellence in Services", Palermo, Italy, 31 August-1 September 2015; pp. 227-242.

30. Calzati, V.; De Salvo, P. (Eds.) Le Strategie per una Valorizzazione Sostenibile del Territorio: Il Valore Della Lentezza, Della Qualità e Dell'identità per il Turismo del Futuro; FrancoAngeli: Milan, Italy, 2012; Volume 31.

31. Heitmann, S.; Robinson, P.; Povey, G. In Slow Tourism. In Research Themes for Tourism; Robinson, P., Heitmann, S., Dieke, P., Eds.; CABI: Wallingford, UK, 2011.

32. Dickinson, J.E.; Lumsdon, L.M.; Robbins, D. Slow travel: Issues for tourism and climate change. J. Sustain. Tour. 2011, 19, 281-300. [CrossRef]

33. Caffyn, A. Advocating and implementing slow tourism. Tour. Recreat. Res. 2012, 37, 77-80. [CrossRef]

34. Nocifora, E.; De Salvo, P.; Calzati, V. Territori Lenti e Turismo di Qualità, Prospettive Innovative per lo Sviluppo di un Turismo Sostenibile; Franco Angeli: Milan, Italy, 2011.

35. Putnam, R.D. The prosperous community. Am. Prospect 1993, 4, 35-42.

36. UNWTO Annual Report 2013; World Tourism Organization: Madrid, Spain, 2014. Available online: http:/ / www2.unwto.org/publication/unwto-annual-report-2013 (accessed on 26 February 2018).

37. Sitarz, D. Agenda 21: The Earth Summit Strategy to Save Our Planet; Earthpress: Bristol, UK, 1993.

38. Pareglio, S.; Grasso, M.; Scancassiani, W.; Repossi, A. Guida europea all'Agenda 21 locale. La Sostenibilita Ambientale: Linee Guida per L'azione Locale. Fondazione Lombardia per l'Ambiente. 1999. Available online: http://www.comunecasaldiprincipe.it/oldsite/Agenda21/documenti_A21/Guida\% 20Europea\%20Agenda\%2021\%20Locale.pdf (accessed on 26 February 2018).

39. Tacchi, E.M. Villaggi Globali e Metropoli Locale: Professionalità, Tecnologie, Valori e Atteggiamenti in una Lombardia Multiculturale; FrancoAngeli: Milan, Italy, 2001; Volume 360.

40. Chhabra, D. Sustainable Marketing of Cultural and Heritage Tourism; Routledge: London, UK, 2010.

41. Sanchez, J.; Callarisa, L.; Rodriguez, R.M.; Moliner, M.A. Perceived value of the purchase of a tourism product. Tour. Manag. 2006, 27, 394-409. [CrossRef]

42. Knox, P.; Mayer, H. Small Town Sustainability: Economic, Social, and Environmental Innovation; Walter de Gruyter: Berlin, Germany, 2013.

43. Ritchie, J.B.; Crouch, G.I. The Competitive Destination: A Sustainable Tourism Perspective; Cabi: Wallingford, UK, 2003.

44. Ogorelc, A. Residents' perceptions of tourism impacts and sustainable tourism development. Int. J. Sustain. Econ. 2009, 1, 373-387. [CrossRef]

45. Tixier, M. Tourism at the crossroads of economic, social and environmental considerations. Int. J. Manag. Bus. 2010, 1, 103-122.

46. Brundtland, G.H. Report of the World Commission on Environment and Development: "Our Common Future"; United Nations: New York, NY, USA, 1987. Available online: http:/ / www.un-documents.net/our-commonfuture.pdf (accessed on 26 February 2018).

47. Andriola, L.; Manente, M. Turismo Durevole e Sviluppo Sostenibile: Il Quadro di Riferimento Italiano; Enea: Milan, Italy, 2000. 
48. Cruz, R.G. Toward the Development of Sustainable Tourism Indicators: An Analysis of Sustainable Tourism Programs and Practices among Asean National Tourism Organizations. Sustainable Tourism, 2005. Available online: https:/ / pascn.pids.gov.ph/files/Discussions\%20Papers/2003/2003-06.PDF (accessed on 26 February 2018).

49. Goossens, C. Tourism information and pleasure motivation. Ann. Tour. Res. 2000, 27, 301-321. [CrossRef]

50. Fonte, M. Slow food's presidia: What do small producers do with big retailers? In Between the Local and the Global; Emerald Group Publishing Limited: Bingley, UK, 2006; pp. 203-240.

51. Gannon, A. Mastering change: A new paradigm in building positive futures for rural communities. In Proceedings of the Positive Rural Futures Conference, Biloela, Australia, 28-30 May 1998; pp. $28-30$.

52. Trauer, B. Conceptualizing special interest tourism—frameworks for analysis. Tour. Manag. 2006, 27, $183-200$. [CrossRef]

53. Ritchie, B.W.; Tkaczynski, A.; Faulks, P. Understanding the motivation and travel behavior of cycle tourists using involvement profiles. J. Travel Tour. Mark. 2010, 27, 409-425. [CrossRef]

54. Palmer, A.; Bejou, D. Tourism destination marketing alliances. Ann. Tour. Res. 1995, 22, 616-629. [CrossRef]

55. Novelli, M.; Schmitz, B.; Spencer, T. Networks, clusters and innovation in tourism: A UK experience. Tour. Manag. 2006, 27, 1141-1152. [CrossRef]

56. Beritelli, P.; Bieger, T.; Laesser, C. Destination governance: Using corporate governance theories as a foundation for effective destination management. J. Travel Res. 2007, 46, 96-107. [CrossRef]

57. Wang, Y.R. Tourism and hospitality management in China. Int. J. Hosp. Manag. 2008, 3, 323-324. [CrossRef]

58. Buhalis, D. Tourism distribution channels: Practices and processes. In Tourism Distribution Channels: Practices, Issues and Transformations; Cengage Learning: London, UK, 2001; pp. 7-32.

59. Song, H. Tourism Supply Chain Management; Routledge: London, UK, 2012; Volume 23.

60. Jamal, T.B.; Getz, D. Collaboration theory and community tourism planning. Ann. Tour. Res. 1995, 22, 186-204. [CrossRef]

61. Beritelli, P. Cooperation among prominent actors in a tourist destination. Ann. Tour. Res. 2011, 38, 607-629. [CrossRef]

62. Haugland, S.A.; Ness, H.; Grønseth, B.O.; Aarstad, J. Development of tourism destinations: An integrated multilevel perspective. Ann. Tour. Res. 2011, 38, 268-290. [CrossRef]

63. Getz, D.; Jamal, T.B. The environment-community symbiosis: A case for collaborative tourism planning. J. Sustain. Tour. 1994, 2, 152-173. [CrossRef]

64. Ossola, P.; Meo Colombo, C. The impact of Trust on Organizational Success: The Case of Coopetiton in Tourism Destinations. In Proceedings of the TTRA 2014, Brugge, Belgium, 18-20 June 2014; pp. 489-504.

65. Yeh, S.S.; Chen, C.; Liu, Y.C. Nostalgic emotion, experiential value, destination image, and place attachment of cultural tourists. In Advances in Hospitality and Leisure; Emerald Group Publishing Limited: Bingley, UK, 2012; pp. 167-187.

66. Sainaghi, R. I cluster di imprese alberghiere: uno strumento innovativo per valutare le performance delle destinazioni turistiche. In Economia e Diritto del Terziario; Franco Angeli: Milan, Italy, 2006.

67. Cantone, L.; Risitano, M.; Testa, P. Strategie di sviluppo delle destinazioni turistiche e ruolo della marca territoriale. In Mercati e Competitività; Franco Angeli: Milan, Italy, 2007.

68. Vigar, G.; Healey, P. Territorial integration and'plan-led'planning. In Planning Practice and Research; Routlege: London, UK, 1999; pp. 153-169.

69. Wilson, S.; Fesenmaier, D.R.; Fesenmaier, J.; Van Es, J.C. Factors for success in rural tourism development. J. Travel Res. 2001, 40, 132-138. [CrossRef]

70. Liu, Z. Sustainable tourism development: A critique. J. Sustain. Tour. 2003, 11, 459-475. [CrossRef]

71. Richards, G.; Hall, D. (Eds.) Tourism and Sustainable Community Development; Psychology Press, Routlege: London, UK, 2003; Volume 7.

72. Paget, E.; Dimanche, F.; Mounet, J.P. A tourism innovation case: An actor-network approach. Ann. Tour. Res. 2010, 37, 828-847. [CrossRef]

73. Schuett, M.A.; Holmes, T.P. Using a collaborative approach to developing a regional bicycle tourism plan. J. Hosp. Leis. Mark. 1996, 4, 83-95. [CrossRef]

74. Macchiavelli, A. Tourist destinations as integrated systems. Tour. Rev. 2001, 56, 6-11. [CrossRef]

75. Telfer, D.J. The evolution of tourism and development theory. Tour. Dev. Concepts Issues 2002, 35-80.

76. Ghoshal, S. Global strategy: An organizing framework. Strateg. Manag. J. 1987, 8, 425-440. [CrossRef] 
77. Scarpato, R. Gastronomy as a tourist product: The perspective of gastronomy studies. In Tourism and Gastronomy; Routledge: London, UK, 2002.

78. Stamboulis, Y.; Skayannis, P. Innovation strategies and technology for experience-based tourism. Tour. Manag. 2003, 24, 35-43. [CrossRef]

79. Formato, R. Cicloturismo: Strategie di Sviluppo e Benefici per le Destinazioni Turistiche; Edizioni Scientifiche Italiane: Napoli, Italy, 2009.

80. Privitera, D. I Parchi e il cicloturismo: Integrazione strategica per lo sviluppo locale. Agribus. Paesaggio Ambient. 2011, 14, 184-190.

81. Yeoman, I.; Brass, D.; McMahon-Beattie, U. Current issue in tourism: The authentic tourist. Tour. Manag. 2008, 28, 1128-1138. [CrossRef]

82. Mihalič, T. Environmental management of a tourist destination: A factor of tourism competitiveness. Tour. Manag. 2000, 21, 65-78. [CrossRef]

83. Simonsen, P.S.; Jørgensen, B.; Robbins, D. Cycling Tourism; Unit of Tourism Research at Research Centre of Bornholm: Bornholm, Sweden, 1998.

84. Lumsdon, L. Cycle tourism in Britain. Insights 1996, 3, 27-32.

85. Ritchie, B.W. Bicycle tourism in the South Island of New Zealand: Planning and management issues. Tour. Manag. 1998, 19, 567-582. [CrossRef]

86. Weston, R.; Mota, J.C. Low carbon tourism travel: Cycling, walking and trails. Tour. Plan. Dev. 2012, 9, 1-3. [CrossRef]

87. World Tourism Organization. (2013). UNWTO Annual Report. 2012. Available online: http:/ /www2.unwto. org/publication/ unwto-annual-report-2012 (accessed on 26 February 2018).

88. Lumsdon, L.; Page, S.J. Tourism and Transport: Issues and Agenda for the New Millennium; Elsevier Science Ltd.: Amsterdam, The Netherlands, 2004.

89. Moscardo, G.; Pearce, P.L. Life cycle, tourist motivation and transport: Some consequences for the tourist experience. Tour. Transp. 2004, 29. [CrossRef]

90. Vladica, F. Understanding Entertainment Value: An Investigation into the Subjectivity of People Who Experience Entertainment. Ph.D. Thesis, Ryerson University, Toronto, Canada, 2012. Available online: http://digital.library.ryerson.ca/islandora/object/RULA:1375/datastream/OBJ/ download/Understanding_entertainment_value_an_investigation_into_the_subjectivity_of_people_ who_experience_entertainment.pdf (accessed on 26 February 2018).

91. Lamont, M. Reinventing the wheel: A definitional discussion of bicycle tourism. J. Sport Tour. 2009, 14, 5-23. [CrossRef]

92. Provincia Autonoma di Trento. Cicloturismo e Cicloturisti, Osservatorio Provinciale per il Turismo. Trento, Italy, 2010. Available online: http:/ / www.turismo.provincia.tn.it/binary/pat_turismo_new/report_ ricerche/Report_bici.1284379418.pdf (accessed on 26 February 2018).

93. Faulks, P.; Ritchie, B.W.; Fluker, M. Cycle Tourism in Australia: An Investigation into its Size and Scope; Sustainable Tourism CRC: Gold Coast, Australia, 2007; Available online: http://atfiles.org/files/pdf/ Faulks-Austraila-Cycle-Tourism.pdf (accessed on 26 February 2018).

94. Cope, M.; Doxford, D.; Hill, T. Monitoring tourism on the UK's first long-distance cycle route. J. Sustain. Tour. 1998, 6, 210-223. [CrossRef]

95. Weed, M.; Bull, C.; Brown, M.; Dowse, S.; Lovell, J.; Mansfield, L.; Wellard, I. A systematic review and meta-analyses of the potential local economic impact of tourism and leisure cycling and the development of an evidence-based market segmentation. Tour. Rev. Int. 2014, 18, 37-55. [CrossRef]

96. Burns, H.; Dudzik, J.; Kola, L.; McCulloch, M. Investigating Impacts of Cycle Tourism in Ontario; Ryerson University: Toronto, ON, Canada, 2014.

97. Gantar, A.; Kočiš, D.; Pehnec, M. How to Develop Cycle Tourism? Project-Bicy. 2012. Available online: http:/ / www.bicy.it/docs/35/How_to_develop_cycle_tourism_ang.pdf (accessed on 3 May 2018).

98. Ritchie, B.W.; Hall, C.M. Bicycle tourism and regional development: A New Zealand case study. Anatolia 1999, 10, 89-112. [CrossRef]

99. Lumsdon, L. Transport and tourism: Cycle tourism-A model for sustainable development? J. Sustain. Tour. 2000, 8, 361-377. [CrossRef]

100. Jamal, T.; Stronza, A. Collaboration theory and tourism practice in protected areas: Stakeholders, structuring and sustainability. J. Sustain. Tour. 2009, 17, 169-189. [CrossRef] 
101. Waligo, V.M.; Clarke, J.; Hawkins, R. Implementing sustainable tourism: A multi-stakeholder involvement management framework. Tour. Manag. 2013, 36, 342-353. [CrossRef]

102. Kenawy, E.H.; Shaw, D. Developing a more effective regional planning framework in Egypt: The case of ecotourism. Sustain. Tour. VI 2014, 187, 77.

103. Caruso, A.; Napoli, A. Percorsi di Mobilità Sostenibili Lungo le Valli dei Fiumi Simeto e Salso: Ipotesi di Recupero Come Greenway Della Linea Ferroviaria Dismessa “Motta S. Anastasia-Regalbuto”. Ph.D. Thesis, Politecnico di Torino, Turin, Italy, 2010.

104. Giacomel, A.; Lanzani, A.; Novak, C. Infrastrutture e Spazi Aperti Attraversati; Territorio, Franco Angeli: Milan, Italy, 2010.

105. Garrett-Peltier, H. Pedestrian and Bicycle Infrastructure: A National Study of Employment Impacts; Political Economy Research Institute: Amherst, MA, USA, 2011. Available online: https:/ /www.peri.umass.edu/ publication/item/427-pedestrian-and-bicycle-infrastructure-a-national-study-of-employment-impacts (accessed on 26 February 2018).

106. Høyer, K.G. Sustainable tourism or sustainable mobility? The Norwegian case. J. Sustain. Tour. 2000, 8, 147-160. [CrossRef]

107. Butler, R. (Ed.) The Tourism Area Life Cycle; Channel View Publications: Bristol, UK, 2006; Volume 1.

108. Rode, P.; Floater, G.; Thomopoulos, N.; Docherty, J.; Schwinger, P.; Mahendra, A.; Fang, W. Accessibility in cities: Transport and urban form. In Disrupting Mobility; Springer: Cham, Switzerland, 2017.

109. Pucher, J.; Komanoff, C.; Schimek, P. Bicycling renaissance in North America? Recent trends and alternative policies to promote bicycling. Transp. Res. Part A Policy Pract. 1999, 33, 625-654. [CrossRef]

110. Lane, B. Sustainable rural tourism strategies: A tool for development and conservation. J. Sustain. Tour. 1994, 2, 102-111. [CrossRef]

111. Meschik, M. Reshaping city traffic towards sustainability why transport policy should favor the bicycle instead of car traffic. Procedia-Soc. Behav. Sci. 2012, 48, 495-504. [CrossRef]

112. Freeman, R.; Thomlinson, E. Mountain bike tourism and community development in British Columbia: Critical success factors for the future. Tour. Rev. Int. 2014, 18, 9-22. [CrossRef]

113. Smith, M.; Puczkó, L. Health and Wellness Tourism; Routledge: London, UK, 2008.

114. Bassett, D.R.; Pucher, J., Jr.; Buehler, R.; Thompson, D.L.; Crouter, S.E. Walking, cycling, and obesity rates in Europe, North America, and Australia. J. Phys. Act. Health 2008, 5, 795-814. [CrossRef] [PubMed]

115. European Commission. Infrastrutture verdi-Rafforzare il Capitale Naturale in Europa. Comunicazione della Commissione al Parlamento Europeo, al Consiglio, al comitato Economico e Sociale Europeo e al Comitato delle Regioni. Bruxelles, 2013. Available online: http:/ / eur-lex.europa.eu/resource.html?uri= cellar:d41348f2-01d5-4abe-b817-4c73e6f1b2df.0005.03/DOC_1\&format=PDF (accessed on 26 February 2018).

116. Timothy, D.J.; Boyd, S.W. Tourism and Trails: Cultural, Ecological and Management Issues; Channel View Publications: Bristol, UK, 2014; Volume 64.

117. Wearing, S.; Neil, J. Ecotourism: Impacts, Potentials and Possibilities? Routledge: London, UK, 2009.

118. Matos, R. Can slow tourism bring new life to alpine regions? In the Tourism and Leisure Industry: Shaping the Future; The Haworth Hospitality Press: Haworth, UK, 2004; pp. 93-103.

119. Magris, M.; Ross, D. Different Ways of Cycling? In Innovative Perspectives on Tourism Discourse; IGI Global: Hershey, PA, USA, 2017; p. 265.

120. Croce, E.; Perri, G. Carta Delle Produzioni Agroalimentari di Cisternino in Valle d'Itria; Meridies: Chieti, Italy, 2010.

121. Eisenhardt, K.M. Building theories from case study research. Acad. Manag. Rev. 1989, 14, 532-550. [CrossRef]

122. Yin, R.K. Case Study Research: Design and Methods, 5th ed.; SAGE Publication: London, UK, 2013.

123. Moretti, A. Turismo in Piemonte. Evoluzione di un Settore Economico Strategico in una Regione in Trasformazione. Working Papers MEMOTEF. 2015. Available online: http://eprints.bice.rm.cnr.it/10321/ (accessed on 26 February 2018).

124. Regione Piemonte. Piemonte e Turismo. Scenari Internazionali, Trend dei Mercati e Prodotti Turistici Piemontesi. 2009. Available online: http://www.ontit.it/opencms/opencms/ont/it/documenti/02087 (accessed on 26 February 2018).

125. Marchesini, D.; Mazzi, B.; Spada, R. Pàlmer, Borraccia e via! Storia e Leggende Della Bicicletta e del Ciclismo; Ediciclo Editore: Portogruaro, Italy, 2001; Volume 1.

126. Bailey, K.D.; Rossi, M. Metodi Della Ricerca Sociale; Il Mulino: Bologna, Italy, 1995.

127. Saunders, M.N. Research Methods for Business Students, 5/e; Pearson Education India: Delhi, India, 2011. 
128. Logar, I. Sustainable tourism management in Crikvenica, Croatia: An assessment of policy instruments. Tour. Manag. 2010, 31, 125-135. [CrossRef]

129. Timur, S.; Getz, D. A network perspective on managing stakeholders for sustainable urban tourism. Int. J. Contemp. Hosp. Manag. 2008, 20, 445-461. [CrossRef]

130. Krippendorff, K.; Bock, M.A. The Content Analysis Reader; Sage: London, UK, 2009.

131. Dall'Ara, G. Manuale Dell'albergo Diffuso. L'idea, la Gestione, il Marketing Dell'ospitalità Diffusa: L'idea, la Gestione, il Marketing Dell'ospitalità Diffusa; FrancoAngeli: Milan, Italy, 2015.

132. Weaver, D.; Oppermann, M. Tourism Management; John Wiley and Sons: Hoboken, NJ, USA, 2000.

133. Brandenburger, A.M.; Nalebuff, B.J. Co-Opetition; Crown Business: New York, NY, USA, 2011.

134. Camera di Commercio Varese. Available online: http://www.va.camcom.it/files/stat_prezzi/ SchedaTurismoConsuntivo2016.pdf (accessed on 6 April 2018).

135. Regione Liguria. Available online: https://www.regione.liguria.it/homepage/turismo/osservatorioturistico-regionale.html (accessed on 6 April 2018).

136. Regione Piemonte. Available online: http://www.piemonte-turismo.it/wp-content/uploads/2017/04/ FlussiTuristici2016.pdf (accessed on 6 April 2018).

137. Li, X.; Roth, D. Learning question classifiers. In Proceedings of the 19th International Conference on Computational Linguistics, Taipei, Taiwan, 24 August-1 September 2002; Association for Computational Linguistics: Stroudsburg, PA, USA, 2002; pp. 1-7.

138. Becken, S. Tourism and transport: The sustainability dilemma. J. Sustain. Tour. 2006, 14, 113-116. [CrossRef]

139. Dickinson, J.E.; Dickinson, J.A. Local transport and social representations: Challenging the assumptions for sustainable tourism. J. Sustain. Tour. 2006, 14, 192-208. [CrossRef]

140. Ritchie, B.; Jay, G. Commentary-'Local Agenda 21 and Community Participation in Tourism Policy and Planning: Future or Fallacy'by Jackson and Morpeth. Curr. Issues Tour. 1999, 2, 39-46. [CrossRef]

141. Cushing, S. European Cycle Tourism. In European Cycle Routes; Sustrans: Bristol, UK, 1997; pp. 10-12.

142. Weston, R.; Davies, N.; Lumsdon, L.; McGrath, P.; Peeters, P.; Eijgelaar, E.; Piket, P. The European cycle Route Network Eurovelo. European Union, 2012. Available online: https:/ / www.cstt.nl/userdata/documents / finalreport-eurovelo2012.pdf (accessed on 26 February 2018).

143. Hunter Cycling Network. Cycle Tourism in the Hunter Region. Report Prepared by Arup Consultants. 2005. Available online: http://www.yooyahcloud.com/CYCLETOURISMAUSTRALIA/cDb2nc/Cycle_Tourism_ Potential_in_Australia.pdf (accessed on 26 February 2018).

144. Chapman, L. Transport and climate change: A review. J. Trans. Geogr. 2007, 15, 354-367. [CrossRef]

145. Downward, P.; Lumsdon, L. The development of recreational cycle routes: An evaluation of user needs. Manag. Leis. 2001, 6, 50-60. [CrossRef]

146. Weaver, D.B. Sustainable Tourism; Butterworth-Heinemann: Oxford, UK, 2006.

(C) 2018 by the authors. Licensee MDPI, Basel, Switzerland. This article is an open access article distributed under the terms and conditions of the Creative Commons Attribution (CC BY) license (http://creativecommons.org/licenses/by/4.0/). 